\title{
What does It Mean to be Ethical in Research? What should It Mean? \\ MOKHAMMAD ANWAR ${ }^{1}$ \\ ${ }^{1}$ Lecturer and Researcher at the Department of Management and Business, Faculty of Economics and Business, The University of Padjadjaran (UNPAD). \\ Email: mokhamad.anwar@fe.unpad.ac.id
}

\begin{abstract}
Research Ethics has become one of the most important issues in research activities. Many professional associations, government agencies, and universities have approved specific codes, rules, and policies relating to research ethics. Nuremberg Code 1947 has been a prominent reference for being adopted by organizations in conducting research ethics. This paper tries to explain what research ethics means, how important ethics in research activities, and some ethics principles which many experts shed light on and currently prevail in many organizations including universities. In the end of this paper, it is revealed some of those principles that could be more appropriate to be paid more attention related with the qualitative and quantitative methods employed.
\end{abstract}

Keywords: Research ethics, ethics Principles

\section{Apa yang Dimaksud Etika dalam Penelitian ? Apa Harus Itu Maksudnya?}

\begin{abstract}
Abstrak
Etika penelitian telah menjadi salah satu masalah yang paling penting dalam kegiatan penelitian. Banyak asosiasi profesional, lembaga pemerintah, dan Universitas telah menyetujui kode spesifik, aturan dan kebijakan-kebijakan yang berkaitan dengan etika penelitian. Nuremberg kode 1947 telah menjadi tokoh acuan untuk diadopsi oleh organisasi dalam melakukan penelitian etika. Karya ini mencoba menjelaskan apa arti etika penelitian, betapa pentingnya etika dalam kegiatan penelitian, dan beberapa prinsip etika yang banyak ahli menerapkan pada dan saat ini berlaku di banyak organisasi termasuk Universitas. Di akhir tulisan ini, ia mengungkapkan beberapa prinsip-prinsip yang dapat lebih tepat untuk diperhatikan berkaitan dengan metode kualitatif dan kuantitatif.
\end{abstract}

Kata kunci: Penelitian etika, prinsip-prinsip etika 


\section{INTRODUCTION}

Research Ethics has become one of the most important issues in research activities. Many professional associations, government agencies, and universities have approved specific codes, rules, and policies relating to research ethics. Nuremberg Code 1947 has been a prominent reference for being adopted by organizations in conducting research ethics.

This issue is important since a research itself would involve human beings, an entity or a company as an object of the study, obtaining and processing data and dissemination of the findings. All aspects can lead researchers to consider the ethical principles before the research commenced.

\section{LITERATURE REVIEW}

\section{What is Research Ethics?}

Many definitions about research ethics can be revealed. Ethics itself can be defined as moral principles that determine how we think and act in particular situations and Research ethics is the ethics of how you carry out your work (Maylor and Blackmon, 2005:281). Brewis and Wray-Bliss (2008) postulate ethics as compliance with rules and emphasizes the avoidance to respondents, while Coghlan and Brannick (2007) state that ethics, in the context of research, which have typically been discussed in terms of the traditional empirical research paradigms, are taken to refer to not doing harm, not breaching confidentiality, not distorting the data, and so on. From above definitions, it can be concluded that research ethics are moral principles that should be obeyed in research activities and which are refer to not doing harm, not breaching confidentiality, not distorting data and so on.

Ethics in research found the momentum since Nuremberg Code was developed in 1947. The Nuremberg code was built after some unethical practices and trials, which were experimented by Nazi regime during the World War II, were sought by Allied Forces. Kenny (2008) explains that prominent members of the Allied Forces proposed the Nuremberg Code in order to provide a mechanism that captured the learning from the trials which gave a clear international set of principles to inform future research and experimentation on human subjects. She also states that The Nuremberg Code dealt particularly with research on or with human subjects. The guiding principles of the Nuremberg Code are namely voluntary consent, informed consent, right to withdraw, avoidance of harm and suffering, duty and responsibility of the researcher to the participant, the expertise and qualifications of the researcher, are reflected in contemporary codes of practice and ethical guidelines (Kenny, 2008).

\section{How important is Ethics in Research?}

Ethics in research is very important because the research frame and circumstances need participations from all parties and that ethics can become guidelines for researchers to conduct their research for making sure that there are no parties who are in harm or hurt. Coghlan and Brannick (2007) see the research action as a system that the participation, from all parties especially researcher and participants (individuals, groups, organizations and communities), is based on the assumption that the members of the system understand the process and take the significant action. While Maylor and Blackmon (2005:280) say that "ethics ensured that nobody is actually or potentially harmed as a result of your work. This is a very minimal goal given the potential for good that a study can have".

Today in research, as Maylor and Blackmon (2005) state, that ethics has become as not only 'nice if we have got time' but also it has become 'must do' in research. It is like that since the consequences of being unethical in research would entail negative points for our research. They add that "ethical behaviour will not necessarily improve your study, but behaving unethically will certainly adversely affect your work". From those ideas, we can take into account that we should better make sure that we conduct each aspects of our research gently in order to have the best quality in research not only in its content itself but also in the highest ethical standard fulfilment.

Discussing about in what area of sciences we need to take into account of research ethics, Collis and Hussey (2003:37) state that 'it is easy to think of ethics being important in the natural sciences, such as medicine, but even in the social sciences it is difficult to conduct much research at all without running in to ethical 
argument'. It means that ethical issue has been a very important aspect in conducting researches not only in natural sciences stream, but also in social sciences stream. Furthermore, Collis and Hussey state that we have to consider a number of different ethical issues and find out what rules there may be for conducting research at an early stage in our study. Based on those explanations, it would be better that before conducting research, we consider and pay attention some codes of conducts or ethical guidelines that related to the topic of the research undertaken.

In social sciences, as Kenny (2008) reveals that the incorporation of ethical guidelines into professional associations is evident in the social science domain. She also points out that some examples such as American Association of Public Opinion Research (AAPOR) adopted a 'Code of Professional Ethical Practice' in 1977, The Australian Psychologist Society (APS) incorporated ethical guidelines into its 'Code of Professional Practice' in 1986, British Psychological Society (BPS) adopted 'Code of Conduct for Psychologist' in 1993, British Sociological Association (BSA) adopted 'Statement of Ethical Practice' in 1992 and many other associations did so.

Especially in management studies, Bryman and Bell (2007:127) have shed light on that "ethics in business and management research bring us into a realm in which the role of values in the research process becomes a topic of concern". They also add that questions about ethics in business and management also bring in the role of professional associations, such as the American Academy of Management (AoM) and the Market Research Society (MRS), which have formulated codes of ethics on behalf of their member.

\section{RESULTS AND DISCUSSION}

\section{Ethical Principles in Research}

There are some ethical principles that should be conducted in research. Those are mainly taken into code of practice or ethical guidelines in various professional associations, universities etc. Many experts in this field have revealed some of those with any additional principles with the different points of views. Several principles that have always shown up and well classified by Diener and Crandall (Bryman and Bell, 2007): informed consent, avoiding harm to participants, invasion of privacy, and deception. Other principles or ethical considerations are data protection, reciprocity and trust, affiliation and conflicts of interest. In this paper, I would like to explain those principles briefly particularly for the four main principles mentioned and will then continue by exploring what principles that should be pointed out regarding our research in management.

We start with the first ethical principle, namely, informed consent. This principle means, as Bryman and Bell (2007:137) state that "prospective research participants should be given as much information as might be needed to make an informed decision about whether or not they wish to participate in a study". With this principle, we should inform the potential participants about some aspects of the study prior to the research started. With this principle we can also know that there should not be any duress for participants and the basis for participants involved in research is voluntary. Informed consent, according to BERA (British Educational Research Association), as stated by Kenny (2008), has the meaning that, participants should be made aware of the aims, purposes, and consequences of the research. Indeed, that principle would be beneficial for the research participants since that will bring the participants in safer position regarding any consequences that would happen related to their involvement in the research.

This informed consent principle has also some weaknesses as many other experts say. Collis and Hussey (2003:38) say "in any research project it is ethical to inform potential participants of the purpose of the research and to obtain their agreement to their participation. This can present problems in gaining access and obtaining valid responses". They furthermore describe an example of conducting research in a laboratory experiment with the disclosure of the purpose of research prior to the research begin. That activity would have the implication of altering their behavioural responses and distort the research findings. Indeed, in some cases, we would have any limitation accessed and worry about the untrue responses from respondents if this principle is strictly obeyed. Regarding this problem, to overcome it and to have natural responses from participants, some approaches have been suggested by Maylor 
and Blackmon (2005:282). They suggest some solutions: 1) be truthful, but vague and imprecise. 2) get consent after the study (post hoc) instead of at the beginning. 3) Avoid the issue by using the credibility of our institution or supervisor, by saying 'they wouldn't allow me to do anything unethical'.

Bryman and Bell (2007:139) also point out that there are hotly debated about this informed consent principle regarding the disguised or covert observation in which in this kind of method, the researcher's true identity is unknown. They said that "Covert observation transgresses this principle, because participants are not given the opportunity to refuse to cooperate. They are involved whether they like it or not". That case entails BSA (The British Sociological Association) Statement of Ethical Practice does suggest that researchers should 'as far as possible' seek to achieve informed consent, but it then goes even further in relation to cover research (Bryman and Bell, 2007). We know that covert observation is usually employed in order to have better opportunities to obtain specific information about the research topic.

The second ethical principle discussing in this paper is avoiding harm to participants. This principle will guide us to be careful in treating participants in research. As Bryman and Bell (2007) state that Research that is likely to harm the participants is regarded by most people as unacceptable. The question then is that what is harm? Bryman and Bell (2007:133) cite the definition of harm from Diener and Crandal, that "Harm can entail a number of facets: physical harm, harm to participants' development or self esteem, stress, harm to career prospects or future employment and inducing subjects to perform reprehensible acts". From that definition we can state that the classification of harm in this regard comprises of physical and psychological disturbance to participants. From that point of view, it seems that researchers should be careful and pay more attention in every single action undertaken in order not to harm the participants in their research.

Regarding this principle, John B. Kervin has shed light on two questions that should be addressed by researchers in their checklist prior to other questions (Collis and Hussey, 2003). Those questions are 1)
Will the research process harm participants or those about whom information is gathered (indirect participants)? and 2) Are the findings of this research likely to cause harm to others not involved in this research?. These two questions should be addressed by researchers in order to make sure that there are no harms to participants and other related parties in their researches.

Maylor and Blackmon (2005:280) put this principle as the minimum ethical standard that should be attained by researcher. They say "A minimum ethical standard is to do no harm. A higher goal is to find a way that your research project can benefit the organization and individuals involved". Moreover they give a suggestion that researchers should stick with the principle "treat others as you yourself would want to be treated and provide the organization and individuals involved in your work". The AoM (Academy of Management) Code of Ethical Conduct states that it is the responsibility of the researcher to assess carefully the possibility of harm to research participants and to the extent that it is possible, the possibility of harm should be minimized (Bryman and Bell, 2007). Those explanations bring us to the conclusion that researchers should be aware and careful in their action in order not to harm the research participants.

This principle is not a pure thing that anybody can address it without any difficulties. Bryman and Bell (2007: 136) say "one of the problems with the harm to participants' principle is that it is not possible to identify in all circumstances whether or not harm is likely, though that fact should not be taken to mean that there is no point in seeking to protect them". To address the problem, Bryman and Bell (2007) state that AoM Code of Ethical Conduct has recommended the involvement of the third party as a means of protecting research participants' interests by stating that research plans involving human participants should be reviewed by an appropriate third party such as a university human subjects committee or a focus group of potential participants.

This principle has also connected with the issue of maintaining the confidentiality of records and anonymity of accounts. This means that researchers should maintain the identities and records of 
individuals and organizations confidentially. Bryman and Bell (2007) reveal that AoM Code of Ethical Conduct has recommended that issues relating to confidentiality and anonymity should be negotiated and agreed with potential research participants and if confidentiality and anonymity is requested, this must be honoured. From that idea, we can state that researchers should take care when the research results or findings would be published to ensure that individuals or organizations are not identified or identifiable unless they have permission to pass on in a form that allows them to be identified.

The third ethical principle discussed in this paper is avoiding invasion of privacy. This principle is also important for researchers to conduct. Bryman and Bells (2007) stated that the right to privacy is a tenet that many of us hold dear, and transgressions of that right in the name of research are not regarded as acceptable. They also show how MRS (Market Research Society) that has paid attention in the MRS, Code of Conduct and Guidelines: "the objectives of any study do not give researchers a special right to intrude on a respondent's privacy nor to abandon normal respect for an individual's values" (Bryman and Bell, 2007:139). This principle should be viewed that it is ethical for researchers to respect privacy of participants and value whatever the decision taken by the participants regarding to answer or not to answer every single questions in the interview that researcher asked. Indeed, it is usually happened that many respondents will refuse certain questions that they feel intruding their privacy. Bryman and Bell (2007) also recommended a suggestion that the researchers should treat each case sensitively and individually and giving a respondent a genuine opportunity to withdraw.

Again, covert methods can violate this principle as well as the informed consent principle, since that the participants are not being given the opportunity to refuse invasions of their privacy. However, such methods have the advantage of being able to get the information that would not have revealed if they had not known about the status of the researcher (Bryman and Bell, 2007).

The last ethical research principle discussed in this paper is avoiding deception. Bryman and Bell
(2007:141) state that "Deception occurs when researchers represent their research as something other than what it is". There are two cases that have been pointed out by Bryman and Bell (2007) regarding the practice of Deception in the researches. Those are 'The obedience to authority study' by Milgram, and 'An example of an ethical fieldwork dilemma' by Holliday. The first case was classified as deception since the participants are led to believe they are administering real electric shocks, and the second one is the practice of pretending to be a student who was interested in small firms in order to get information about a competitor's product.

There is an important message from The AoM, Code of Conduct regarding this issue, (Bryman, 2007:141) states "Deception should be minimized, and when necessary, the degree and effects must be mitigated as much as possible. Researchers should carefully weigh the gains achieved against the cost in human dignity. To the extent that concealment or deception is necessary, the researcher must provide a full and accurate explanation to participants at the conclusion of the study, including counselling, if appropriate". From that message, it can be drawn the conclusion that researchers should consider thoroughly about the possibility of doing deception in their research.

In addition to the four main ethical principles, Bryman and Bell (2007) suggested that researchers should pay attention on other ethical considerations such as: 1) data protection legislation related to the confidentiality of information, 2) the role of reciprocity in determining the relationship between the researcher and research participants, 3) need to declare sources of funding and support that may affect the affiliations of the researcher, causing conflicts of interest.

Those ethical research principles would be beneficial for us in undertaking research in the area of management studies for both methods employed, either by qualitative method as well as a quantitative one. For undertaking the qualitative method, all principles should be addressed since it certainly requires contacting with human being as the research objects, i.e. when they obtain the data through surveys and interview. Although if researchers employ a quantitative method where they use secondary 
data, several principles should also be addressed in their study. One of the principles is avoiding harm to participants. The possibility of revealing a certain company which experiencing bad performance in the research would entail a financial harm to the company related to its reputation. In the case that the study results could have the possibility to be published in some magazines or newspapers and that would influence the perception of the investors and customers of the company, it is more appropriate that name of a company mentioned in the research is anonymous. The principle of anonymity and confidentiality attached to avoiding harm principle could be used in this context. The second principle that could be taken into our considerations is that avoiding deception. By complying with this principle, we should never do the research processes diversely with the actual conditions since the data gathering and processing until the disclosure of research results. This principle would guide us to be honest in conducting research and reveal the result research as what it is.

\section{CONCLUSION}

Research Ethics has become one of the most important issues in research activities. Many professional associations, government agencies, and universities have approved specific codes, rules, and policies relating to research ethics. Ethics itself can be defined as moral principles that determine how we think and act in particular situations and Research ethics is the ethics of how you carry out your work (Maylor and Blackmon, 2005).

Ethics in research is very important because the research frame and circumstances need participations from all parties and that ethics can become guidelines for researchers to conduct their research to make sure that there are no parties who are in harm or hurt.

Several ethical principles in research that have always shown up and well classified by Diener and Crandall (Bryman and Bell, 2007) are informed consent, avoiding harm to participants, invasion of privacy, and deception. Other principles or ethical considerations are data protection, reciprocity and trust, affiliation and conflicts of interest.

\section{REFERENCES}

Brewis, J., \& Wray-Bliss, E. (2008). Re-searching Ethics: Towards a More Reflexive Critical Management Studies. Organization Studies, 29 (12): 1521-1540. SAGE Publications.

Bryman, Alan, \& Emma, B. (2007). Business Research Methods, Second Edition. Oxford University Press.

Certo, \& Samuel, C. (2000). Modern Management: Diversity, Quality, Ethics, and the Global Environment, Eight Edition, Prentice Hall Inc.

Coghlan, David, \& Teresa, B. (2007). Doing Action Research in Your Organization. Second Edtion, Reprint in 2007. SAGE Publications.

Collis, Jill, \& Roger, H. (2003). Business Research: $A$ Practical Guide for Undergraduate and Postgraduate Students, Second Edition. Palgrave Macmillan Ltd.

Johnson, Phil, \& Joanne, D. (2004). Understanding Management Research. Reprinted 2004. SAGE Publications Ltd.

Kenny, \& Aidan. (2008). Towards a Model of Critical Ethics to Inform the Research Process in Postgraduate Research. Paper submitted for Peer review to The Dublin Institute of Technology (DIT), Open Access Journal Level 3, URL link http://level3.dit.ie/. Retrieved from http://ssrn.com/abstract=1147584.

Maylor, Harvey, \& Kate, B. (2005). Researching Business and Management. Palgrave Macmillan Ltd.

Mikic, Stefan, Gareth, R. T., White, \& Azley A. R. (2009). A Knowledge Review: Implications for Future Research and Practical Application. International Journal of Business and Management, Vol. 4, No. 1, January 2009. 
Smith, Mark, E., Richard, T., \& Paul, R. J. (2008). Management Research, Third Edition SAGE Publications Ltd.

Stern, Judy, E. \& Deni, E. (1997). The Ethics for Scientific Research: A Guide Book for Course
Development. University Press of New England, Hanover.

Van de Ven, A. H. (2007). Engaged Scholarship: A Guide for Organizational and Social Research. Oxford, UK: Oxford University Press. 